\title{
THE INTERPLAY OF INCUMBENCY, POLITICAL DINASTY AND CORRUPTION IN INDONESIA: ARE POLITICAL DYNASTIES THE CAUSE OF CORRUPTION IN INDONESIA?
}

\author{
Titin Purwaningsih, ${ }^{1}$ Bambang Eka Cahya Widodo \\ Universitas Muhammadiyah, Yogyakarta
}

\begin{abstract}
:
This article analyzes the interplay of incumbent, political dynasty and corruption in Indonesia from the perspective of good governance. In the last local elections held in Indonesia, three interesting issues came into the limelight: the increasing incumbent power, political dynasty phenomena, and corruption at the local level. Based on the qualitative data analysis, this research shows that the direct local head election provided greater opportunities for incumbents to build their political dynasties to perpetuate their power. Some analysis considered that political dynasties are the cause of corruption. Nevertheless, corruption at the local level is performed by both dynastic and non-dynastic local head. Thus, minimizing corruption is not achieved by the restriction of political dynasties but by strengthening the control of the government. There are five key points in the supervision process to strengthen the control on the government, namely supervision in the political recruitment in the election process, bureaucratic neutrality, transparency and accountability in budgeting, and supervision of local policies to avoid pork barrel policy.
\end{abstract}

Keywords: Incumbency, Political Dynasty, Corruption, Local Head Election, Government

Título en Castellano: Relación entre Ocupaciones de Cargo, Dinastía Política y Corrupción en Indonesia

\section{Resumen:}

Este artículo analiza la relación entre ocupación de cargo, dinastía política y corrupción en Indonesia desde una perspectiva del buen gobierno. En las últimas elecciones locales en Indonesia, tres interesantes cuestiones salieron a la luz: el aumento del poder de los titulares del cargo, el fenómeno de la dinastía política y la corrupción a nivel local. Basándose en un análisis cualitativo de datos, esta investigación demuestra que estas elecciones locales directas dieron la oportunidad a los que ya eran titulares del puesto de construir sus dinastías políticas para prolongar su poder. No obstante, la corrupción a nivel local es realizada tanto por los jefes locales dinásticos como por los no dinásticos. En consecuencia, la disminución del nivel de corrupción no se consigue restringiendo las dinastías políticas sino reforzando el control sobre el gobierno. Existen cinco puntos de supervisión importantes para reforzar el control sobre el gobierno, los cuales son supervisión del reclutamiento político en los procesos electorales, neutralidad burocrática, transparencia y asunción de responsabilidades en la gestión de fondos, y supervisión de las políticas locales para evitar el clientelismo político.

Palabras Clave: Mandato, Dinastía Política, Corrupción, Elección de Representantes Locales, Gobierno

Copyright $@$ UNISCI, 2019.

Las opiniones expresadas en estos artículos son propias de sus autores, y no reflejan necesariamente la opinión de UNISCI. The views expressed in these articles are those of the authors, and do not necessarily reflect the views of UNISCI.

\footnotetext{
${ }^{1}$ Titin Purwaningsih is Lecturer at Master of Government Affairs and Administration, JK School of Government, Universitas Muhammadiyah Yogyakarta,

E-mail: <titin.p.widodo@gmail.com>

${ }^{2}$ Bambang Eka Cahya Widodo is Lecturer at the Department of Government Affairs and Administration, Universitas Muhammadiyah Yogyakarta

Email: <bec.widodo@gmail.com>

DOI: http://dx.doi.org/10.31439/UNISCI-89
} 


\section{Introduction}

Political dynasties are considered to be the root cause of corruption and also of the hijacking of democracy in Indonesia. This statement would need to be tested by research. Are political dynasties corrupt? Are non-political dynasties not corrupt? Political dynasties are a common phenomenon in developed and underdeveloped countries. They are related to the power of the incumbent. Political dynasty usually is defined as a family who has two or more members as politicians that have political power. In Indonesian perspective, a politician is considered to build a political dynasty as if she/he obtains power and then seeks to strengthen its power by encouraging his/her family to also be a political officer.

There are several ways to build a political dynasty:

1) A leader of a region comes to the end of his mandate and then transfers the power to the family (child or wife) through the local head election. For example: Kediri Region, Bantul Region

2) A politician gains power as the head of a region and then members of the family become legislators. For example: South Sulawesi Province, Banten Province, Pasuruan City, Indramayu Regency, Kutai Kartanegara, Bekasi City and Kendal Regency.

3) A legislator encourages a family member to also be a legislator.

4) A legislator encourages family members to participate in the local head election.

Those phenomena show the force and importance of the incumbents. Lembaga Survey Indonesia (LSI) survey shows that incumbents are becoming dominant in some regions. In 2006, $230(78.77 \%)$ of 296 local head elections contested by incumbent candidates and 62.2 $\%$ of them show their success to manintain their power. Afterwords, in 2010, out of 146 local head elections in 82 regions, or 56\%, were won by incumbents. In 2015, Skala Survey Indonesia (SSI) released a report explaining that $82.5 \%$ of incumbents were nominated as candidates for competing in the elections of 257 regions, out of 264 that held a simultaneous local head election, and $63.2 \%$ of those incumbents were elected. Based on this data, SSI comes to an exciting conclusion that the bigger the number of DPT, the bigger the chance for incumbents to get elected in local head elections. The percentage of incumbents $(82.5 \%)$ was calculated based on incumbent re-candidacy in local elections either as the head or vice head of the regions. Out of the total number of 264 regions, there were 122 regions (46.21\%) whose incumbents were the competing candidates.

Those numbers show the incumbent advantages because society better knows them; thus, they are likely to regain support through their programs while running the government. Due to the terms limit of a local head for a maximum of 2 periods, the incumbents usually nominate their families (children, spouse, sibling, etc.) in the regional head election to perpetuate their political power.

The nomination of incumbent's family members, often considered a characteristic of a political dynasty, as candidates in the local head elections, is still debatable. A good example is the dabate on the decision of the Constitutional Court, overturning the ban against incumbent 's family candidacies in local head elections. They argued that every citizen has the right to elect and be elected, something that is assured by the constitution. Thus, there should be no obstacles for incumbent's family members to be appointed as candidates in local head elections. This decision has triggered the rampant phenomenon of political dynasties.

The minister of home affairs claimed that the number of political dynasties at the local level could reach the figure of 57. Meanwhile based on the collected data, during the 
simultaneous local head elections, there were 33 political dynasties in the local election either on province or municipalities of which twenty-three at the regency level, seven at municipality level and three at the provincial level. Even though the numbers are relatively small compared to the total number of Indonesian local head elections, these numbers, however, show that local elections provide more opportunities for political families to establish and strengthen their power. This issue contradicts the democracy concept that gives equal access to all citizens to elect and be elected. On the other hand, a political dynasty is often considered as the source of corruption and abuse of power. The corruption case of Ratu Atut in Banten, Fuad Amin in Bangkalan and Haryati in Klaten often considered as proof of the negative impacts of political dynasty phenomenon.

The fundamental issue in the implementation of local head elections is how to minimize the abuse of power by incumbents. Incumbents have more significant opportunities to retain power by using government resources, either through bureaucratic ranks, regional budgets, facilities and infrastructure, including pork-barrel policy. Based on these issues, this article will analyze the practices of political dynasties and incumbents in local head elections. This article further analyzes the possible alternatives to minimize the weaknesses of political dynasties and incumbents in carrying out and implementing good governance principles.

Figure 1. Number of Political Dynasty Candidates

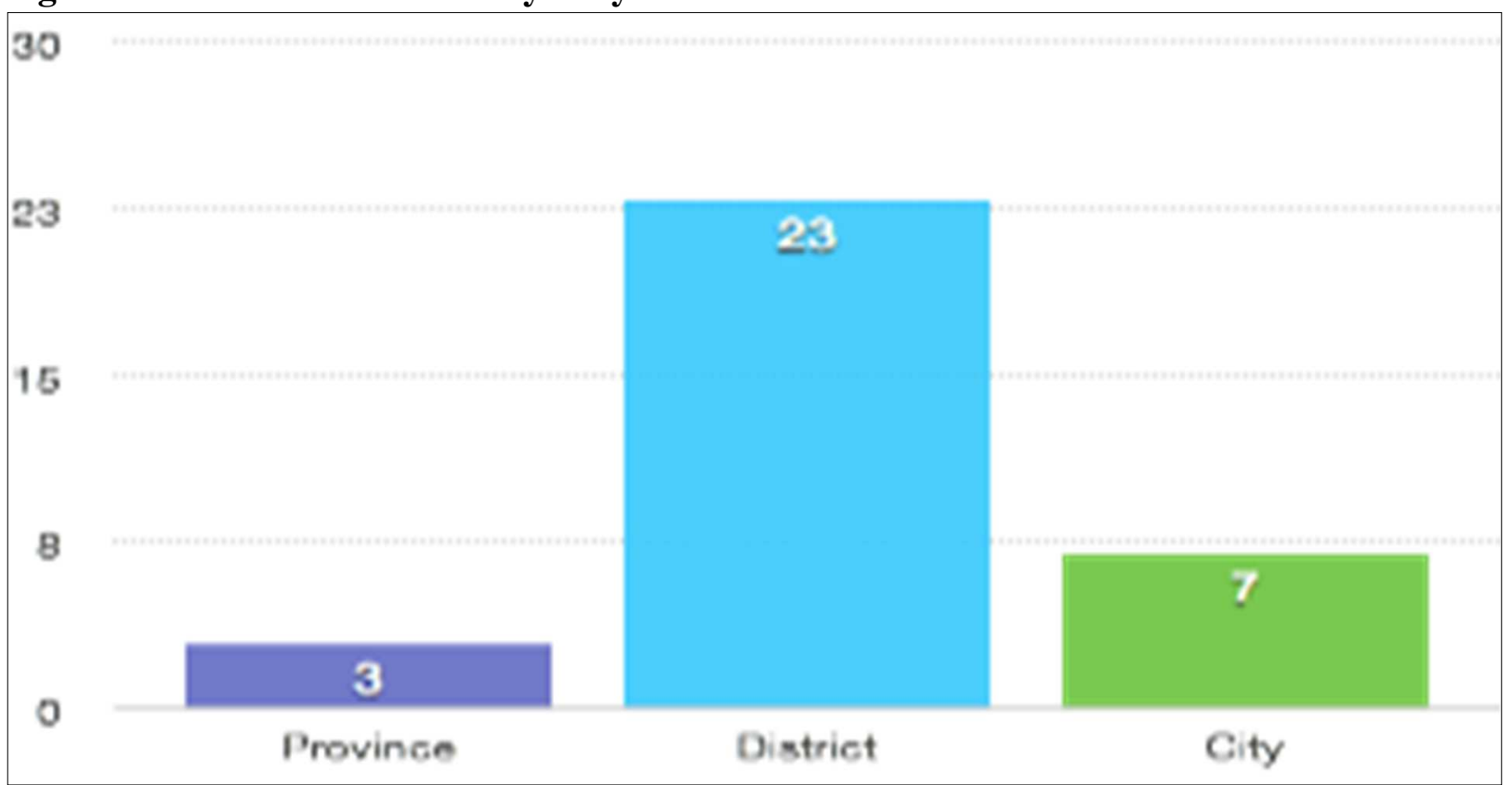

Source: Author elaboration (2019)

\section{Theoretical Framework}

\subsection{Political Dynasty}

In Indonesian politics, the term political dynasty means every politician who tries to maintain and strengthen its political power by putting her/his relatives on the political office. However, Hess defines political dynasty as '....any family that has had at least four members, in the same name, elected to the federal office'. ${ }^{3}$. Based on this definition, we can say that a political dynasty occurs when there are at least four family members who occupy political positions. In the context of American politics, a political dynasty also includes several generations. Therefore, after he analyses of some sources we can say that only a few families in Indonesia

\footnotetext{
${ }^{3}$ Kurtz II, Donn M.: “The Political Family: A Contemporary View”, Sociological Perspectives, Vol. 32 , no 3
} (1989), pp. 331-352. 
fit in the category of political dynasty, as is the case of Yasin Limpo family in South Sulawesi (8 family members occupying political offices) and Ratu Atut family in Banten (8 family members). If only two family members occupy political positions, such as the wife continuing his husband's power, it cannot be considered as a political dynasty by definition but only an embryo of a political dynasty. The phenomenon of the candidacy of incumbent family members in a local election is considered to fall within the concept of political family.

According to Kurtz, a political family exists if a family has two or more relatives holding public offices. ${ }^{4}$ Another term for the political family is the political kinship as defined by Casey. Political kinship or political family refers to the candidate who has a tie of affinity or a consanguineous connection with the former political officer within two generations ${ }^{5}$. The concept of political dynasty differs from the concept of political family. Political family means that there are at least two members in the family, either bond by blood or marriage, which hold political positions and they do not have to belong to two different generations. In the long term, a political family may turn into a political dynasty. The concept of a political dynasty in this context does not refer to the word "dynasty" as in the monarchy system, but to "dynasty" in the context of democracy, sometimes called "dynastic democracy".

The development of the political family in the local election may take place in several ways, namely:

- The first political officer in the family to become the Head of Region and followed by the candidacy of his/her children/spouse / other family members in the next election as the cases at Kediri and Bantul;

- The first political officer in the family to become Head of Region and followed by his family members who become members of the legislature; as the cases at South Sulawesi Province, Banten Province, Pasuruan City, Indramayu Regency, Kutai Kartanegara, Kendal Regency, Bekasi City and Banda Aceh City;

- The first political officer in the family to become a member of the legislature, followed by other families as members of the legislature as well, both at the same level and or at different levels.

- The first political officer in the family to become a member of the legislature followed by other family members, and then compete in the local head election.

Casey divides political family based on the number of family members involved in politics into three categories, namely: multiple-member association; two-member relationships, and empirical familial effects based on the level of political position held by members of the political family ${ }^{6}$.

\footnotetext{
${ }^{4}$ Ibid.

${ }^{5}$ Casey, Kimberly L. (2008): Political Families in American Electoral Politics, St. Louis, University of Missouri.

${ }^{6}$ Casey, Kimbely L. (2009): Family Matters: The Prevalence and Effects of Political Families in National Politics. Dissertation, University of Missouri.
} 
Table 1. Classification of Political Family Typology

\begin{tabular}{|c|c|}
\hline Multiple Member Association & Definition \\
\hline - Dynasty (defined by Hess 1966) & $\begin{array}{l}\text { Four or more family members with the same } \\
\text { surname elected to presidency, vice } \\
\text { presidency or congress }\end{array}$ \\
\hline - $\quad$ Multimember & $\begin{array}{l}\text { More than two members involved in political } \\
\text { service, does not meet Hess's criteria }\end{array}$ \\
\hline \multicolumn{2}{|l|}{ Two Member Relationship } \\
\hline - $\quad$ Spousal & Married partner \\
\hline - Widow-effect & $\begin{array}{l}\text { Emergence of a partner occurs when spouse } \\
\text { dies. It is not necessarily correlated with direct } \\
\text { succession, although in most cases it is }\end{array}$ \\
\hline - $\quad$ Parent-child & $\begin{array}{l}\text { The most common delineation of political } \\
\text { kinship }\end{array}$ \\
\hline - $\quad$ Sibling & $\begin{array}{l}\text { Usually brothers, however brother and sister } \\
\text { combinations are becoming more prevalent }\end{array}$ \\
\hline - In-law & $\begin{array}{l}\text { Relationship forged through marital, rather } \\
\text { than blood-kin bonds }\end{array}$ \\
\hline - Collateral & $\begin{array}{l}\text { Two person association outside of parent- } \\
\text { child, sibling, spousal or in-law }\end{array}$ \\
\hline - $\quad$ Direct succession & Immediate succession to the same office \\
\hline \multicolumn{2}{|l|}{ Empirical Familian Effects } \\
\hline - $\quad$ Multi-level & $\begin{array}{l}\text { Political candidacy by members at different } \\
\text { levels (local, state, national) politics }\end{array}$ \\
\hline - Multi-state & $\begin{array}{l}\text { Family members run for office in a different } \\
\text { state }\end{array}$ \\
\hline
\end{tabular}

Source: Casey (2009)

Multiple-member associations consist of two types: 1) dynasty, as defined by Hess: four or more family members with same surname elected to the presidency, vice presidency, or congress and 2) multi-member where more than two members involved in political offices. A two-member relationship consists of seven types. First: spousal (married partners). Second: widow effect (emergence of a partner occurs when spouse dies. It is not necessarily correlated with direct succession, although in most cases it is. Third: Parent-child (the most common delineation of political kinship). Fourth: sibling (usually brothers, however, brother and sister combinations are becoming more prevalent). Fifth: In-law (relationship forged trough marital, rather than blood-kin bonds). Sixth: collateral (two-person) associations outside of parent-child, sibling, spousal, or in-law relationship), and Seventh: direct succession (immediate succession to the same office). The empirical familial effect consists of two types: 1) multi-level (political candidacy by members at different levels politics ex. Local, state, nation politics) and 2) multistate (family members run for office in different states). 
Taking into account these categories, a dynasty is part of the political family. Thus, not all political families can be equated to a political dynasty. The concept of political family is more relevant when the rampant phenomenon of relatives involved in politics in Indonesia is analysed. If the political family continues to enlarge its power by positioning its family members in political positions, up to more than four people through several generations, then it can be characterized as dynastic politics. A political family in Indonesia is the forerunner to the politics of dynasty.

The dynastic politics occurs because of the decisive factors of the political candidates from the dynasty in political recruitment. According to Norris (1997), candidates from political dynasties have a good political capital for the election which includes political connections, experience in political parties, work experience, education, and skills in the implementation of legislative functions. In other words, candidates from dynastic politics possess political legacy, both education and political skills, renowned family name, political networks, and financial means for the campaign. In the Indonesian context, rampant political dynasties are influenced by the power of oligarchs in local politics ${ }^{7}$.

For the analysis of rampant political dynasties, Norris used the supply and demand perspective in political recruitment that provides a competitive advantage for the political family in political recruitment. The structures of opportunity given by the political system, the party system and the conditions of society provide excellent opportunities for political families.

Figure 2. Supply and Demand in Political Recruitment

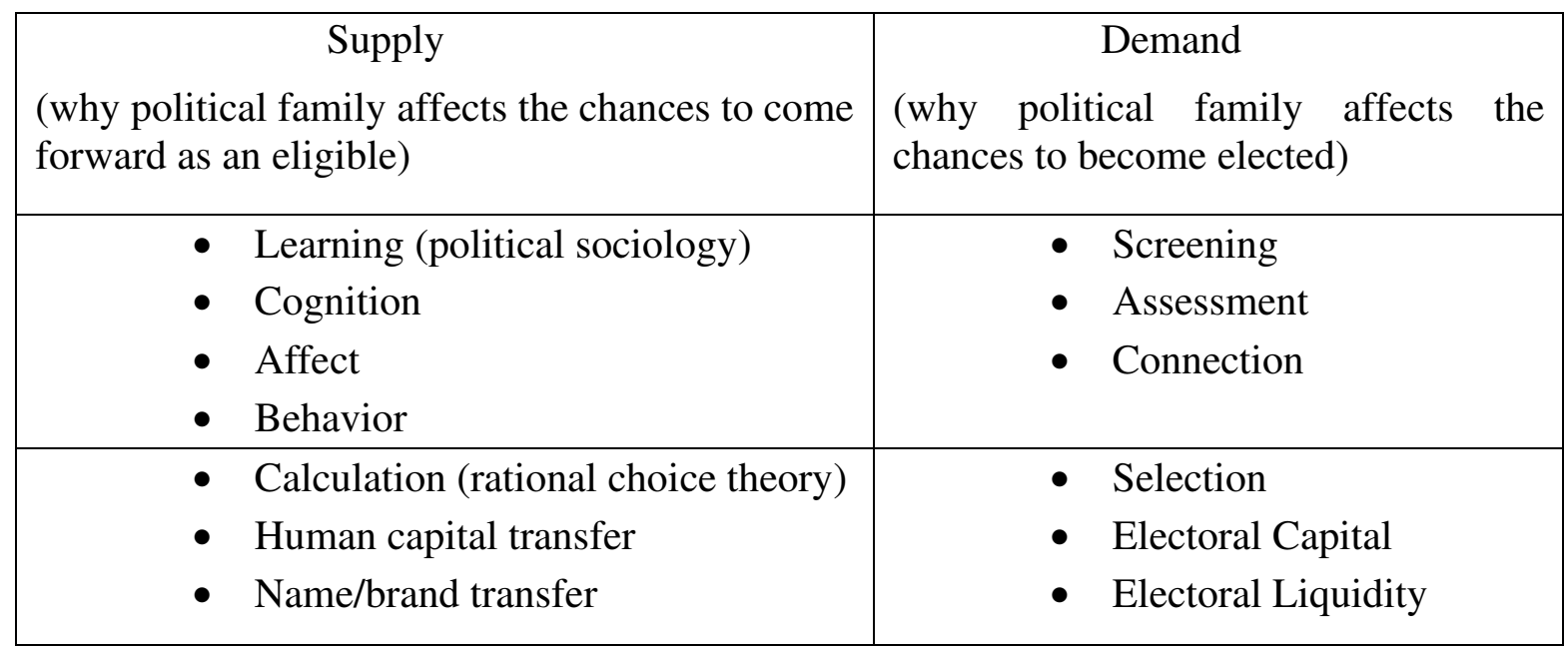

Source: Van Liefferinge \& Stevyers (2009)

Supply and demand in political recruitments are the side effects of the relation between political families and political parties. On the supply side, the political capacities of the candidates from political families are considered taking into consideration the aspects of learning and calculation. Early political socialization conducted by the family provides understanding, skills and political knowledge to the children/relatives.

This socialization carries a cognitive aspect that motivates children/relatives to be interested in politics. The earlier the socialization, the greater affection towards politics may be developed. This socialization will affect the political behaviour of the children/relatives, so cognition, affection and political behaviour is favoured in political recruitment. Moreover, the aspect of calculation, in which candidates who come from political families may have more

\footnotetext{
${ }^{7}$ Norris, Pippa (1997): Passage to Power, Legislative Recruitment in Advanced Democracies, Massachusetts, Harvard University
} 
abundant human capital and publicly renowned family names, will further support the political family in political recruitment.

Figure 3. Structure of Opportunity (external framework for eligibility, candidacy and election)

- Electoral Shifts

- Volatility

- Mediatizations

- Personalization

- Partisan Shifts

- New cadre syndrome

- Societal Shifts

- (post)modernization

Source: Van Liefferinge \& Stevyers (2009)

On the demand side, political parties perform political recruitment through screening and selection. Screening in political recruitment is conducted by looking at the skills possessed by the candidates. Beside the skills, political parties also look at the track record and prospects of the candidates in the assessment process. However, the skill aspect by itself is inadequate, because the closer the candidate to the recruiter, the higher his/her chances to be nominated or recruited. Thus, the electoral capital and electoral liquidity are the determining aspects to be a winner. The candidates who come from the political kinship have higher value of electoral capital and electoral liquidity. Environmental factors such as media and the public also influence political recruitment when looking at the candidates who come from political families. The ability to mediate and use the media as well as the personality of the candidate may affect the public support, thus affecting the electoral volatility. Such recruitment is also influenced by the different support political parties receive and the modernity level of society.

\subsection{Incumbency}

Political dynasty is closely related to incumbents because of the prohibition in Article 7 of Law No. 8 of 2015, which was annulled by the Constitutional Court was related to candidates of incumbent's family. Unfortunately, the author has not found data on the number of candidates for regional head elections included in a political dynasty. Arguably, there were several political dynasties that prevailed in local elections such as Indramayu Regency, Bontang City, Kediri Regency, Gowa Regency, South Tangerang City and Jambi Province. However, there were also some areas where political dynasties failed to win the elections such as Bantul Regency, East Belitung Regency, Pasuruan City, Ogan Kemiring Ilir Regency, and Soppeng Regency. This fact show that political dynasties are not always able to maintain their power.

There are several types of incumbents who participate in local elections, namely 1) pair of prospective incumbents nominated for the second period; there were 21 pair of candidates in the 2015 local elections. 2) Pair of incumbents who broke up the partnership, thus the Regional Head and his/her Deputy become rivals in the election; There were 34 pair of candidates. 3) Incumbents who compete in other regions; and 4) the candidacy of incumbent's family or those who include in the phenomenon of a political dynasty. From this type of incumbents, a political dynasty is only one variant of the incumbent.

An incumbent means an official who hold an office. Recently, the study of an incumbent is quite diverse. The study of an incumbent in developing countries is different compared to that of the developed countries. In developing countries, which are usually former colonies and 
have an authoritarian political character, incumbents are perceived negatively with several reasons ${ }^{8}$. First, incumbents are identical to poor government performance. Second, incumbents perceived to link with corruption. Third, incumbents trace to a combination of term limits, rentseeking and weak political parties, so the quality of the challengers are must higher than the incumbent ${ }^{9}$. Meanwhile, the studies of an incumbent in developed countries observed from a more positive perspective in maintaining power.

People who hold power or a political position try to maintain their power and incumbents have higher chances of regaining their power against their challengers. The incumbency advantage can be divided into three components. The first is the electoral advantages of being in the office (such as the ranking privilege, constituency service, and name recognition). The second is the quality of incumbents (including both the ex-ante quality that got them elected in the first place), and the on-the-job experience that makes them effective legislators), and the third is the deterrence of high-quality challengers. ${ }^{10}$

The enormous opportunities for incumbents in elections often called as incumbency effects because of some reason that his/her benefits comprise privileges, media exposure, fundraising advantages and pork-barrel spending ${ }^{11}$. An incumbent is also assumed to have higher quality than his/her challengers. ${ }^{12}$. Incumbents have long been publicly known, thus making it easier for them to gain public support. Moreover, incumbents also have access to resources that used for their benefits in maintaining support, either through policy or the use of public budget

\section{Research Methods}

This research used descriptive qualitative methods by analyzing incumbents, political dynasties in local elections and good governance practices in Indonesia. Data collection techniques carried out through secondary data from documentation, books, journals, news on the phenomenon of political dynasties in Indonesia, curriculum vitae of each candidate, regulation of the political parties, and other relevant documents. Data analysis carried out by using inductive methods which consist of three interconnected sub-processes, namely data reduction, data presentation and data verification ${ }^{13}$. The qualitative data analysis addressed at every step from research design, during the data collection process and after the final data collection. The data reduction process is a process of data simplification following the direction and focus of the research. After all the necessary data have been collected, summary, grouping and data presentation are done through analysis and interpretation of the data in an attempt to verify and make conclusions.

\section{Discussion and Results}

\subsection{Political Dynasties and Incumbency in Local Elections (Pilkada)}

Article 60 of Law No. 23 of 2014 on Regional Government states that the office term of Regional Heads is 5 years and thereafter may be re-elected within the same position for one more term. Thus, the maximum tenure of the Head of a Region is 10 years. Therefore, the newly

\footnotetext{
${ }^{8}$ Nurmandi, Achmad.and Purnomo, Eko Priyo.: "Making the strategic plan work in local government: a case study of strategic plan implementation in Yogyakarta Special Province (YSP)", International Review of Public Administration, Vol 16, no 2 (2011), pp. 143-164.

${ }^{9}$ Trounstine, Jessica: "Evidence of a Local Incumbency Advantage", Legislative Studies Quarterly, Vol. XXXVI, $\mathrm{n}^{\circ} 2$ (May 2011), pp. 255-280

${ }^{10}$ See Smith, op. cit., p. 34

${ }^{11}$ Egner, Björn; Stoiber, Michael: “A Transferable Incumbency Effect at Local Level Elections: Why It Is Important for Parties to Hold the Mayor", ECPR Joint Session of Workshop, May 2007, Helsink

12 Jacobson, Gary C.; Kernell, Samuel (1981): Strategy and Choice n Congressional Elections, New Haven, Yale University Press

${ }^{13}$ Denzin, Norman K and Lincoln, Yvonna S. (2009): Handbook of Qualitative Research (Translation), Yogyakarta, Pustaka PI, p. 592.
} 
elected Head of a Region tends to nominate himself in the next period. This is reflected in the high percentage of incumbents in the local elections which reached $82.5 \%$ in 2015 local elections and in the high percentage, 63.2\%, of those who won the elections. In 2017 local elections, there were 101 regions which held simultaneous elections, of which incumbents entered in the competition as candidates in 67 elections (66\%). In the 2017 local elections, 153 pair of candidates competed and out of that number, $90(59 \%)$ pairs were incumbent candidates. The big number of incumbent candidates was due to the fact that some of them were already paired as regional head and vice regional head in the running term and some were incumbents who competed against each other (where the Head of Region competes with his/her Vice for winning the election.)

Even though the number of candidates for Regional Head and their Deputy was quite large, the women candidates were still very few, only around $7 \%$. This number was even less reduced if it is compared to that of women candidates in the legislative election due to the affirmative policy of the $30 \%$ quota. Women candidates in local elections are usually publicly known either from their individual achievements or the big names of their husbands or families.

Although the number of incumbents was quite large and usually incumbents have greater chance than their challengers, in reality, incumbents did not always win the elections. In 2015 local election, $63.2 \%$ of incumbents won elections and in 2017 local elections more than $60.65 \%$ won elections. ${ }^{14}$ Thus, $36.8 \%$ of incumbent lost in 2015 local election and $39.35 \%$ of incumbents lost in 2017 local elections.

Figure 4. Number of Incumbents by Sex

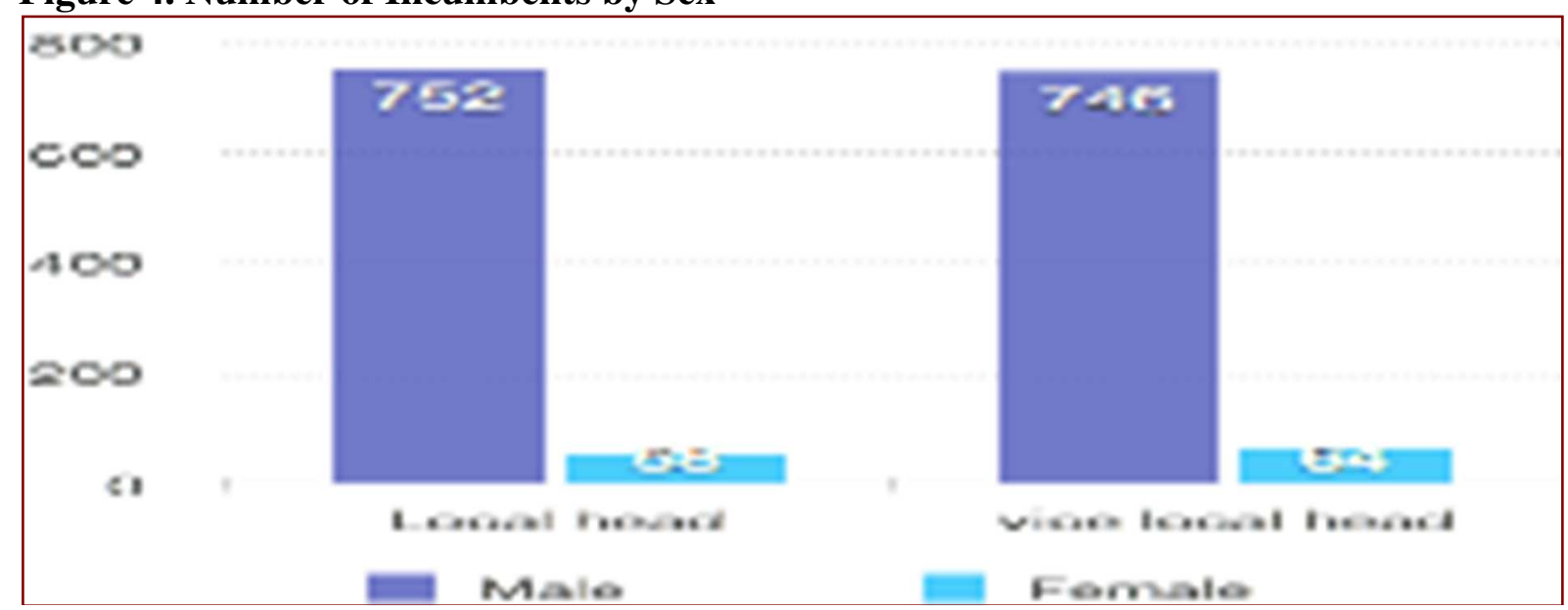

Source: Author elaboration (2019)

There are several arguments for the victory of incumbents. First, the long time of socialization of the incumbents with the public; thus, they are more renowned. In the regional development activities, those incumbents take a leading role so that the public knows them well, both through ceremonial government activities as well as formal and informal interactions with the community. Second, incumbents have access to financial resources so they can use the regional budget to maintain public support. Third, incumbents have access to the bureaucracy and may use it as a political machine to gain public support. Fourth, incumbents are usually supported by big parties because they have high electability. There is a high tendency of political parties to nominate candidates who have high ability to be elected. In such circumstances, it is usually

14 Paath, Carlos KY: "63,2\% Petahana Menangi Pilkada”, Beritasatu.com, 26 January 2016, at https://www.beritasatu.com/nasional/344756/632-petahana-menangi-pilkada. See also Fadli, Andi M. D.; Tobarasi, Indrawan; Rusba, Komeyni: "Kemenangan Petahan dalam Kontestasi Pilkada Serentak 2018: Ditinjau dari Perspektif Powercube”, Jurnal TAPIs, Vol. 14, no 2 (July-December 2018), pp. 116-139. 
challenging to match incumbents' ability, thus big political parties with considerable strength in the parliament will give their support to the incumbents. Fifth, incumbents are considered suspicious in fulfilling their promises during the campaign and successfully improving the service and welfare of the community.

On the other hand, there are some arguments for the defeat of the incumbent in local elections. First, incumbents considered a failure by the community. They appeared as incapable in the realization of their campaign promises and unable to meet the community expectations. Second, society wants to change. There is political saturation, especially if incumbents are also members of the family of the previous incumbents. Third, there are rivalries among fellow incumbents. In the case of incumbents which break up their partnerships, the incumbents of the Heads of Region compete against their Deputy Heads of Region. Thus, the split couples contribute to the number of victories and defeats of incumbents.

Those arguments showed that incumbents have the potential to abuse their official power to maintain public support. There are several possible abuses of power committed by incumbents, including bureaucratic politicization and misuse of the public budget. Bureaucratic politicization may carry out by involving bureaucratic officials as a political machine to gain public support. The manifestation of bureaucratic politicization carries out in two ways. First, through the human resources policy, for example, they promote civil servants who support them, or they mutate/repace who do not support them. Second, through the mobilization of bureaucrats from the highest level to the lowest to give support.

Meanwhile, Government Regulation No. 53 of 2010 prohibits civil servants to provide support to candidates for Regional Head or candidate for Vice Head of Region in the election. However, such prohibition gives dilemma situation for civil servants who are facing higher bureaucratic structures. The bureaucratic inconvenience becomes a lively phenomenon during local elections.

Incumbents often abused the public budget as well. According to FITRA (Indonesia's Forum for Budget Transparency) for example, there are several modes of misuse of local budget committed by incumbents, including 1) through social assistance and grant funds; 2) through populist programs before the elections such as free health and education programs to obtain public support; 3) through financial assistance granted to lower levels of government (financial assistance of Governor to the Regency / City, financial assistance of Regent to the Village); 4) allowances or raises of salaries to bureaucrats; 5) infrastructure development ahead of the elections; 6) misappropriation of village funds; 7) inserting incumbents' interest in the local budget changes ${ }^{15}$..

The misuse of local budget refers to Aspinal (2014), maybe done through patronage and clientelism approach as well as through pork-barrel projects and populistic development programs. The abuse of power is a problematic issue which may lead to fraud in organizing fair elections. We need to anticipate this fraud to maintain a qualified election. How to minimize the possibility of violations committed by incumbents, including violations of dynastic politics?

Political dynasty in the elections occurs because, as we mentioned, there is a limitation of tenure for Regional Heads of maximum two periods, thus to retain the power incumbents push their family members to become candidates for nomination. During the simultaneous elections, there were 33 candidates for Regional Heads from political families, especially related to the power of incumbents. Out of this number, there were four political families in

15 “Awasi! Ini 7 Celah Penyelewangan APBD oleh Petahana Jelang Pilkada”, Batamnews.com, 11 September 2015, at https://www.batamnews.co.id/berita-6615-awasi-ini-7-celah-penyelewengan-apbd-oleh-petahana-jelangpilkada.html 
provincial elections, 21 in the district elections and 8 in city elections. Compared to the total number of provinces in Indonesia, the number of political dynasties at the provincial level reached $11.76 \%$, while at the district level was $5.64 \%$. Although the number is relatively small, it has a considerable impact. At the very least, the government seeks to minimize the political dynasties through the specific Act, even though the Constitutional Court finally annuled it.

\section{Figure 5. Political Family in Concurrent Local Head Election}

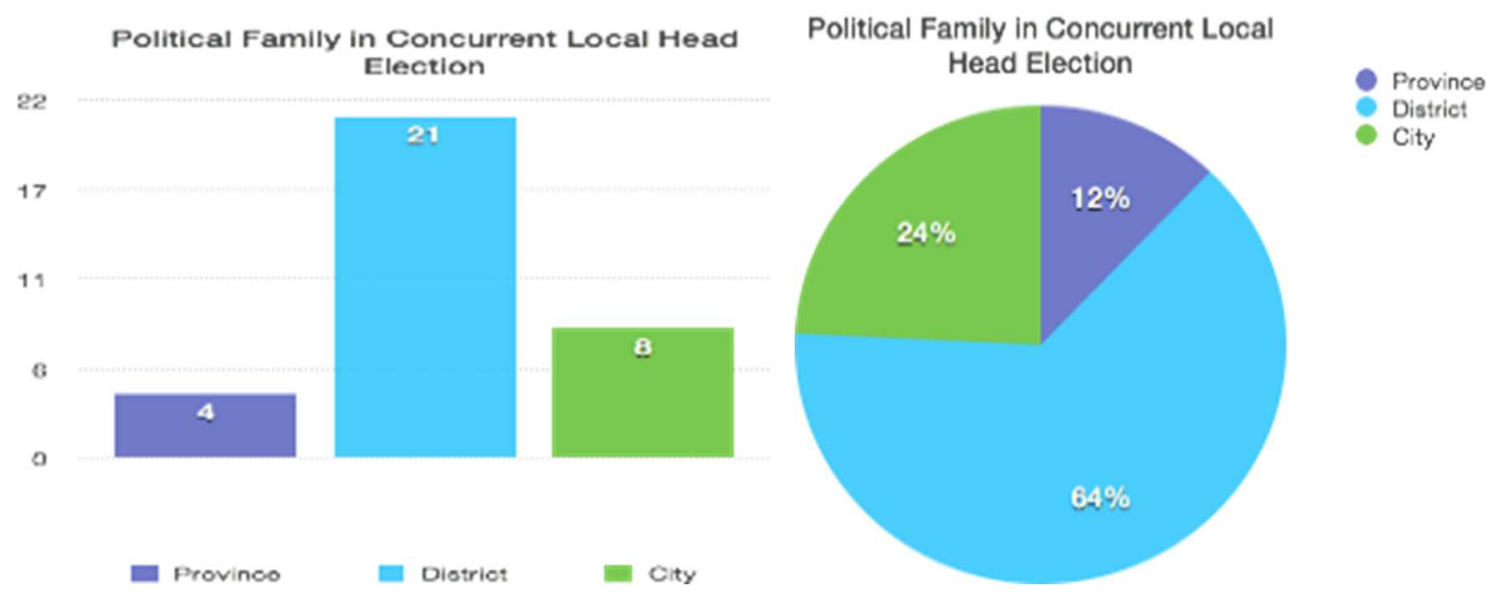

Source: Author elaboration (2019)

Referring to Casey's categories on political dynasties, in the local elections, the spousal category rose to $45 \%$ and to $42 \%$ in the parent-child category ${ }^{16}$. There are attempts by incumbents to prepare their family members before presenting their candidacy for Regional Head. Based on the data, the preparation usually passes through the election first as members of Parliament.

Figure 6. Type of Political Family in Local Head Elections

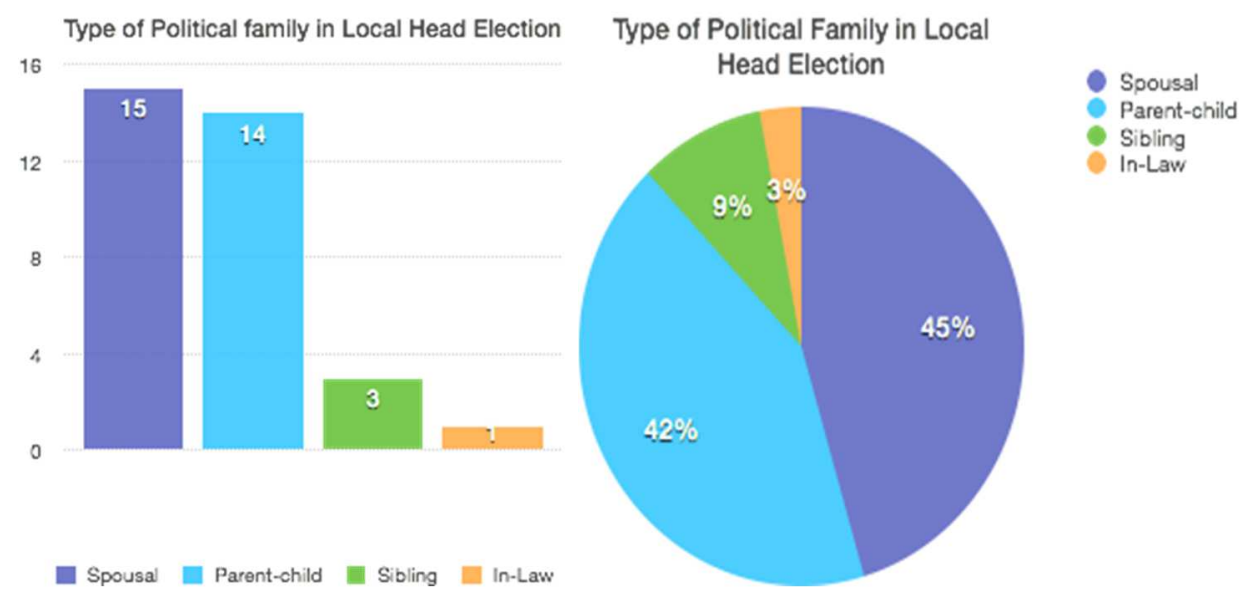

Source: Author elaboration (2019)

Candidates who come from political families have a political legacy as politicians which give them an additional value in term of political experiences. ${ }^{17}$ Therefore, it is the advantage of political families to have a higher chance of establishing incumbency benefits through their

\footnotetext{
${ }^{16}$ See Casey (2009), op. cit.

${ }^{17}$ Dal Bó, Ernesto; Dal Bó, Pedro; Snyder, Jason: "Political Dynasties", Review of Economic Studies, Vol. 76, n 1 (2009), pp. 115-142
} 
family names and resources. "Political families tend to perpetuate themselves - showing a form of political dependence on work in politics" ${ }^{18}$. Besides, political parties also do not want to bother with regeneration or cadre on leadership at the local level; thus, they tend to nominate candidates from political families. From the data of political families who compete in local elections, we can say that they were all supported by prominent political parties or coalitions of major parties which strengthen the design of these families for maintaining their political power and authority.

\subsection{Incumbents, Dynastic Politics, and Corruption}

One crucial argument for limiting the role of political dynasties is ensuring that the administration of the government may run democratically and avoid rampant corruption and/or abuse of power. The Director-General of Regional Autonomy has stated that the efforts to reform the implementation of local government has been meeting difficult obstacles due to political dynasty. Indeed, decentralization and direct election of Regional Heads provide opportunities for local elites to gain and enlarge their power. Along with it, the level of corruption in the regions is also increasing.

The Ministry of Home Affairs claimed that until 2015, there were 343 Heads of Regions who have been dealing with legal cases, either at the Court, Police and the Corruption Eradication Commission (KPK). Meanwhile, KPK claims that in 56 cases Heads of Region are involved in corruption cases of which Governors and Vice Governor committed 12 cases, 23 cases by Regents / Vice Regents and 11 Cases by Mayors / Deputy Mayors, as shown in the following diagram:

\section{Figure 7. Number of Corruption of Local Heads}
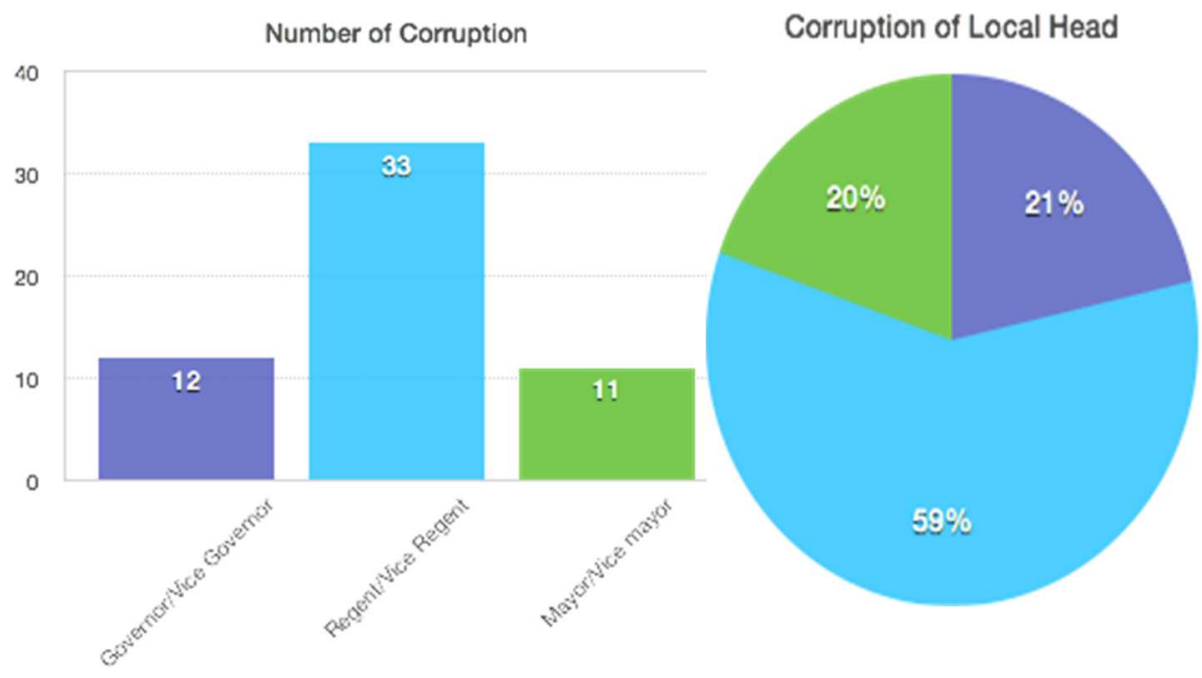

Governor/Nice Governor
Regent/Nice Regent

Mayor Nice mayor

Source: Author elaboration (2019)

The corruption cases being committed by Head of Region / Deputy Head of Region includes 15 cases of misuse of Local Budgets, 17 cases related to bribery in the business permit, eight bribery cases in election dispute resolution, 8 cases in procurement, 4 cases of social assistance grants and four corruption cases in regional development projects. The misuse of local budgets and bribery in business licenses are the two violations that most often occur.

\footnotetext{
${ }^{18}$ See Smith, op. cit., p. 33-34
} 


\section{Figure 8. Various Cases of Corruption of Local Heads}
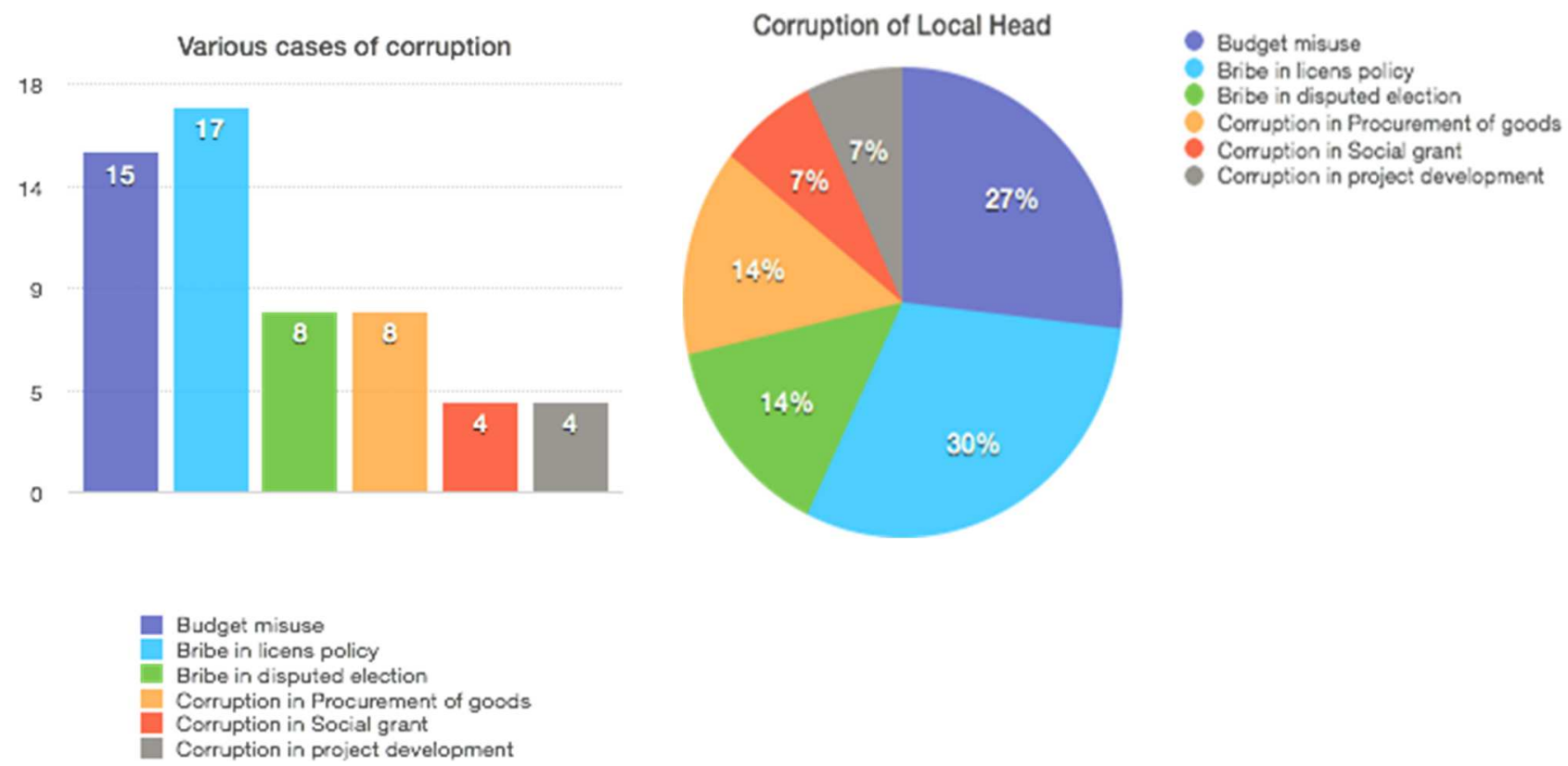

Source: Author elaboration (2019)

Meanwhile, based on data from the ICW, from 2010 to 2015 there were 183 (36.24\%) Regional Heads involved in corruption cases, with the distribution of cases as follows.

\section{Figure 9. Local Heads Corruption}
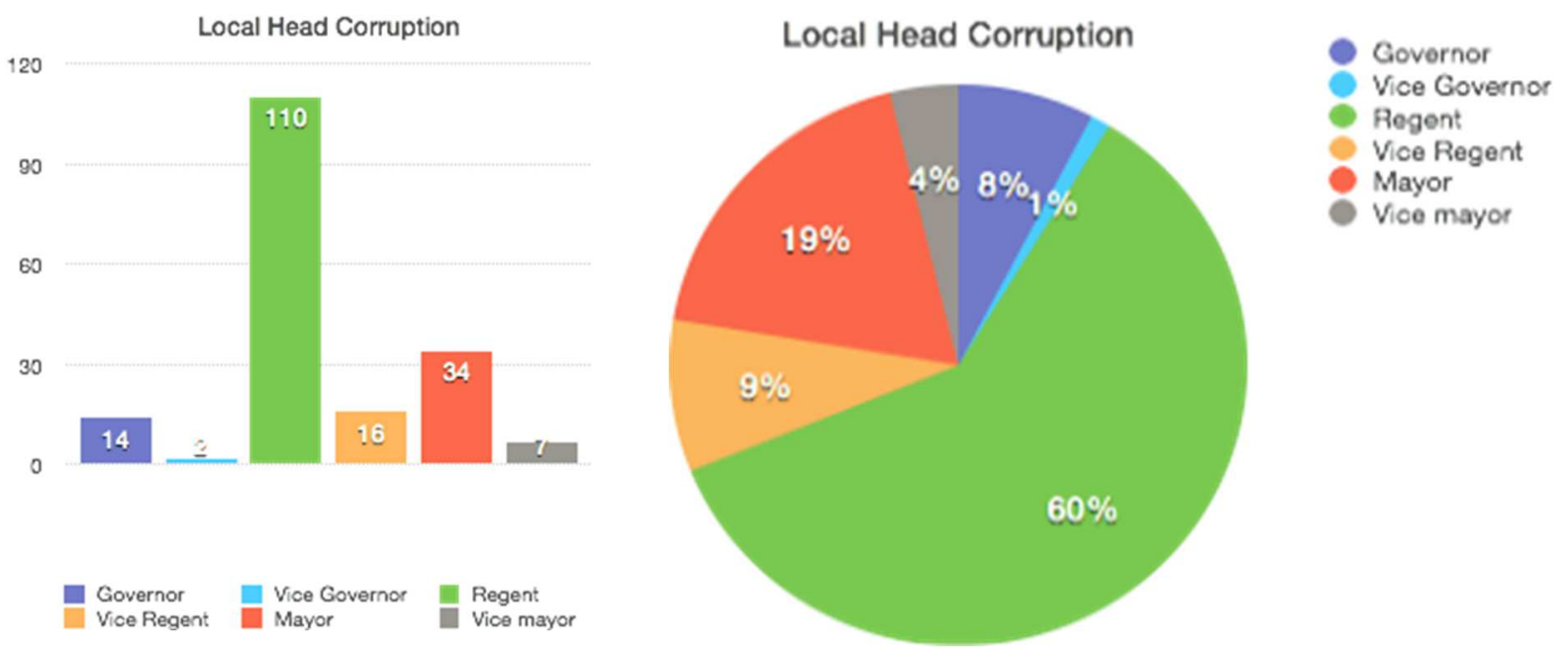

Source: Author elaboration (2019)

The data show that corruptions at the local level mostly involve Regents and reach up to $60 \%$ of the total cases. However, if we see the proportion between the corruption cases and the number of regencies, corruption cases involving Regents amounted to $23.35 \%$, while the corruption cases involving Governors amounted to $41.17 \%$. The corruption rate is so high that it should be the government's priority to push forward the implementation of good and clean government.

The high number of corruption cases involving Heads of Region, according to ICW, has been caused by several factors, among others are an attempt to pay-back political costs, to maintain power and its supporting networks, and to enrich themselves and their groups. In other 
words, the number of corruption cases is related to the high political cost that must be paid by the Regional Heads. Costs incurred by candidates of Regent / Mayor, for example, may reach up to 5 - 10 billion Rupiah and the cost incurred by candidates of Governor may reach up to 20 - 100 billion Rupiah. This figure is too high compared to that of the income of Regents / Mayors, which only amounted to around 400 million Rupiah/year.

Meanwhile, according to BPKP (2016), corruption cases involving Heads of Region are caused by several factors, namely 1) the monopoly of power, 2) discretionary policy, 3) weak accountability, and 4) other factors, such as high cost of elections, lack of competency of the Regional Head, lack of understanding of regulations, and incorrect cultural concepts. ${ }^{19}$ However, as stated by BPKP and ICW, the cost of local elections is the most prominent factor of corruption at the local level. The election cost is not only the cost incurred during the election but also the cost to maintain the political support for the next election. Misuse of the local budget, bribery and budget mark-up in procurement processes are alternatives to be taken to gain additional income to maintain political support.

Minimizing dynastic politics is an effort to fight against rampant corruption at the local level. Most of the considerable corruption cases at the local level in Indonesia have been involving by political families, such as the case of Ratu Atut in Banten, Fuad Amin in Bangkalan and Haryati in Klaten. Now, the question is: is it the case that dynastic politics is the cause of the high rate of corruption in Indonesia?

Figure 10. Local Heads Corruption based on Political Family and Non-Political Family
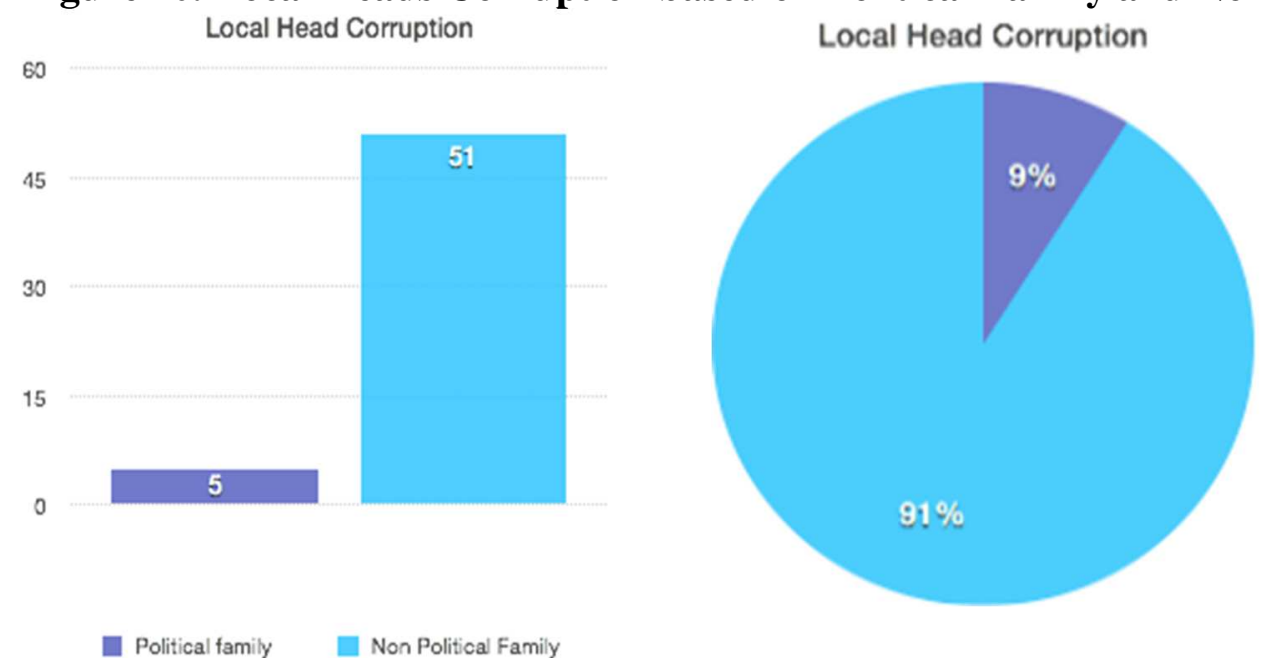

Source: Author elaboration (2019)

The corruption cases involving Heads of Region processed at the KPK can be divided into those which are conducted by Heads of Region from a non-political dynasty, 91\% (51 cases) and those which are conducted by Head of Region from Political Dynasty, 9\% (5 cases). These figures, however, do not indicate that political families at the local level are the causative factor of the rampant corruption because corruption cases committed by Head of Region from nonpolitical dynastic areas is much higher.

\footnotetext{
19 "Faktor-Faktor Penyebab Kepala Daerah Korupsi”, BPKP, 2016, at http://www.bpkp.go.id/puslitbangwas/konten/2674/16.050-Faktor-Faktor-Penyebab-Kepala-Daerah-Korupsi
} 


\section{Figure 11. The Comparison of Dynastic and Non-Dynastic Local Head on Corruption}
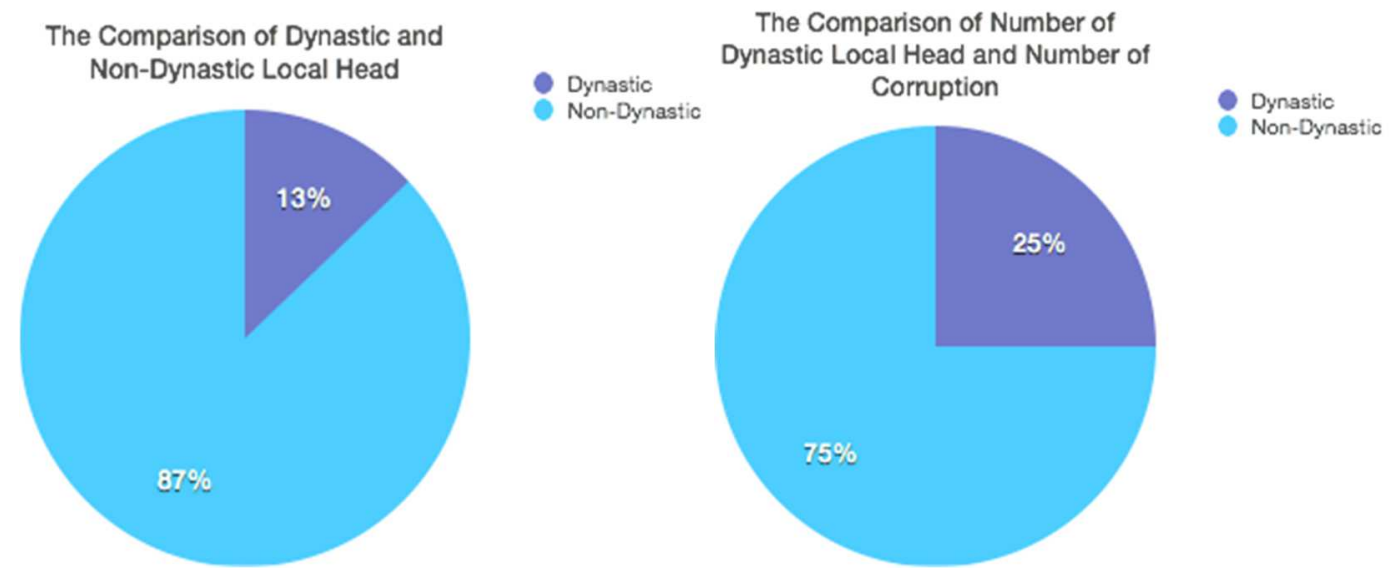

Source: Author elaboration (2019)

The diagrams above showed the number of dynastic-local heads compared to that of nondynastic. In reality, the total number of local heads dynastic is around $13 \%$ of the total number of Heads of Region. Based on the MoHA data, there are at least 61 regions which can be included in the dynastic category. Nevertheless, if all those localdynastic heads would commit corruption, the number would only reach $25 \%$ of the total corruption in Indonesia. It shows that corruption cases in Indonesia are mostly committed by non-dynastic heads rather than by the dynastic ones.

\section{Discussion and Implications}

Decentralization provides opportunities for local elites to gain and strengthen their power. In particular, the direct local elections reinforce the personal aspects of the candidates in the community; thus, popular candidates may have enormous advantages to be elected or reelected.

The tendency to maintain and enlarge political power is indisputable after analyzing the increasing number of incumbents who compete in local elections.

There is also another tendency. When incumbents have been in the position for two terms they try to maintain and extend their influence by nominating their family members in the election; thus, dynastic politics occurs. Nevertheless, the term political family is more appropriate than political dynasty. By definition, political dynasty should involve a minimum of four or more family members in political positions stretching into several generations. While in the Indonesian case, most political families who nominate their family members (spousal and parent-child types) in the local election usually have less than four people who hold political positions.

The re-candidacy of many incumbents in local elections is clear because, theoretically, as we said, incumbents have enormous advantages over their challengers to win the elections. The percentage of incumbents' victory is about $60-65 \%$.

Meanwhile, when competing with another incumbent, the lack of support from major political parties, lack of competences/popularity and the saturation of the society against incumbents are critical factors for the defeat of incumbents. As we said, most candidates who come from political families have already been prepared by their families or incumbents to be active in politics. Those candidates have already been active in politics before competing for the position of Head of Region. They've usually been members of Parliament either at the local or national level. 
According to Norris's theory, the supply of candidates from political families have usually brought with them previous political experiences, especially when they were elected as members of Parliament.

\section{Figure 12. Employment Background of Dynastic Local Heads Candidates}

\section{Employment Background of} Dynastic Local Head Candidate

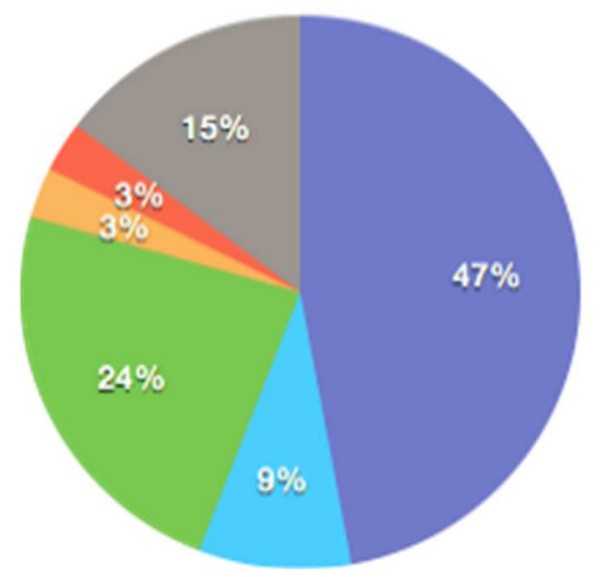

Member of parliaments

Bureaucrats

Entrepreneur

Lecturer

Political Party Officer

No data

Source: Author elaboration (2019)

The diagram above shows that $47 \%$ of Heads of Regions from political families have started their political career as Members of Parliament, while $56 \%$ of them have experiences in governmental business. They inherited political values and cadre in the political families, preparing them to be successors of the families' political activities. It shows first, that most of the candidates from political families have political backgrounds as legislative members before progressing in local elections; and second, that most candidates from political families are spousal $(45 \%)$ and parent-child (42\%), which is the closest kinship relationship of the incumbents.

Dal Bó, Dal Bó, and Snyder (2009) find that legacy candidates are more common following a politician who has enjoyed a long term in office (and thus has had more time to build the incumbency advantage of name recognition and resources), and that political dynasties tend to be self-perpetuating — suggesting a form of career path dependence in politics. ${ }^{20}$

The experiences brought by candidates from political families indicate that they have a higher probability in the process of political recruitment. Besides, they also have higher probability from the side of demand. Most of them get support from major political parties or from a coalition that hold majority seats at local parliaments. Political parties also have a preference to nominate candidates from political families who have high electability, which are usually calculated through surveys. This is evident looking to the turnout votes data:

\footnotetext{
${ }^{20}$ See Dal Bó, Dal Bó, and Snyder, op. cit.
} 


\section{Figure 13. The Percentage of Votes in Election of Dynastic Local Heads}

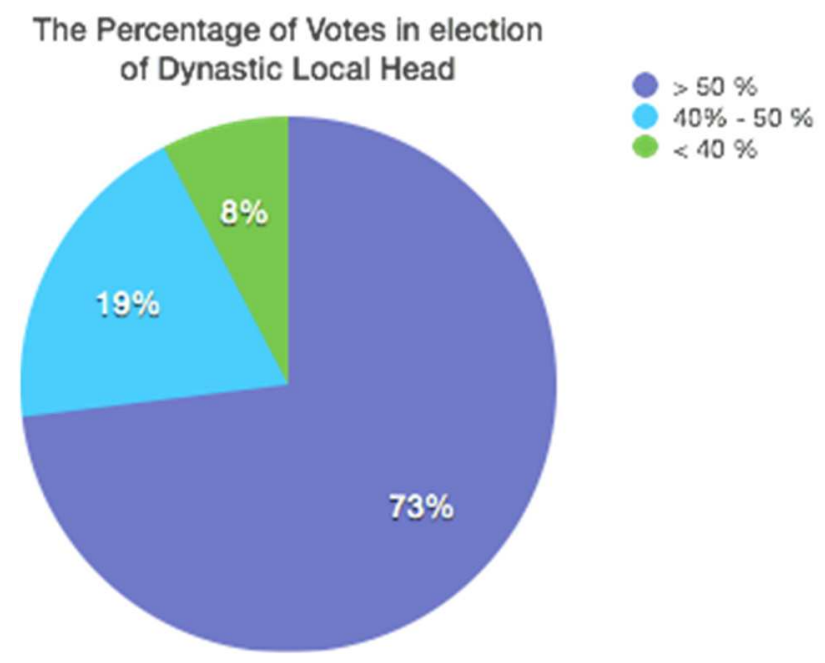

Source: Author elaboration (2019)

The data above shows that $73 \%$ of Heads of Regions from political families received more than $50 \%$ of the votes and even $30.8 \%$ of them received more than $70 \%$. It shows that candidates from political families have a high level of public support. In terms of supply and demand, candidates from political families hold a higher position in addition to the experience in politics and government, popular, and also get reliable support from political parties. Thus, this combination may link up mutually the interest between political parties and political families to maintain and enlarge their political power. Local elections that highlight personal aspects of the candidates may then give incumbents a more significant opportunity to win, including their family member, if competing.

This power monopoly brings a tendency towards authoritarian actions and abuse of power. Corruption committed by Ratu Atut is a concrete example of this case, but that does not mean that the political family is the only source of corruption and abuse of power. Fahri from Perludem stated that: "political dynasties undermine democratic system. Through political dynasties, corruption becomes fertile and uncontrollable". This statement, however, is not in accordance with the results of this study. The data indicate that corruption numbers committed by Head of Regions who come from political families only take $9 \%$ out of the total number corruption case involving Head of Regions. The most significant factor behind the high number of corruption cases committed by the Head of Region, according to ICW and BPKP, is the high cost of local elections which makes the Head of Region, coming from both a political or nonpolitical family, prone to corruption.

An additional concern is whether there exists any correlation between legacy politics and corruption. Chang and Golden find evidence in Italy that the incentives to cultivate a personal vote may be related to higher levels in corruption and money politics due to the pressure on personal promotion for electoral reasons and the burden and stimulous that all this place on candidates for amassing financial resources (sometimes illegally) ${ }^{21}$. It could be the case that the personal advantages of name recognition and inherited resources that legacy candidates possess over non-legacy candidates insulate them from the need to resort to corrupt practices in order to get elected. While non-legacy politicians may feel stronger pressures to engage in illegal fundraising in order to amass the personal resources necessary to be

\footnotetext{
${ }^{21}$ Chang, Eric C. C.; Golden, Miriam A.: "Electoral Systems, District Magnitude, and Corruption”, British Journal of Political Science, Vol. 37, nº 1 (2007), pp. 115-137.
} 
competitive in personalized elections, legacy politicians may exhibit comparatively lower levels of corruption ${ }^{22}$.

Local elections characterized by personal vote provide opportunities for corruption. Nevertheless, incumbents or elected officials from political families are theoretically less prone to corruption because they already have a high political capital. Although, more in-depth research needs for examining this issue, this initial research shows that corruption by the Head of the Regions is carried out by political and non-political families. Minimizing the chances of corruption committed by Regional Heads has to be an important political task

Efforts to minimize the chances of corruption by Head of Regions as proposed by Purwaningsih (2016), consist of five aspects, which include supervision on 1) political recruitment by political parties, whether recruitment is performed based on specific qualifications or through standard procedures. 2) neutrality of the bureaucracy, especially concerning the incumbents who potentially use bureaucracy as a political tool to obtain public support. 3) the use of government budgets and facilities for campaigns. 4) transparency in local budget planning. 5) the risk of pork-barrel policymaking. The point is to bring transparency and accountability in the nomination process of Heads of Regions and improvement of voter's quality and the public participation together. ${ }^{23}$

\section{Conclusion}

Decentralization and direct local head elections give great opportunities for local elites to gain and enlarge their power. The local election is a manifestation of the personal vote, thus providing excellent opportunities for candidates who are known publicly. Thus, there is a tendency for incumbents to maximize their benefits. They usually take an opportunity to perpetuate their power by putting his relatives as successors. In the case of incumbents, there is a fairly normal path they walk through: the establishment of their political families as the forerunner of a political dynasty in Indonesia. The large percentage of the spousal and parentchild type of political family in Indonesia local elections shows this tendency. There is an effort from the political families to perpetuate their legacy in the political activity and political officials. More than $50 \%$ of candidates for Head of Regions who come from political families have political experiences by being active members of political parties and /or active as elected members of Parliament. The political power of incumbents and political dynasties are supported by major political parties that prefer candidates with high electability and have adequate political capital borrowed from political families. Therefore, candidates from political families receive more than $50 \%$ of the votes.

Although political dynasties usually are considered as phenomena that destruct democracy and a causal factor of corruption, the data in this study shows the opposite, that only a small number $(9 \%)$ of corruption cases involve political families. Therefore, the effort to realize good and clean governance should not be carried out by limiting dynastic politics but by ensuring strict supervision instead, especially on five critical points: political recruitment and election, bureaucratic neutrality, transparency and accountability of local budget, and possible pork-barrel policy. Furthermore, it is essential to improve the quality of voters and public political participation.

\footnotetext{
${ }^{22}$ See Smith, op. cit, p. 27

${ }^{23}$ Purwaningsih, Titin: "Politik Dinasti dalam Pemilihan Kepala Daerah", (2016), Makassar, Universitas Hasanuddin.
} 


\section{Bibliography}

Aspinal, Edward; Sukmajati, Mada (eds.). (2014): Politik Uang di Indonesia, Patronase dan Klientelisme pada Pemilu Legislatif 2014, Research Center for Politics and Government UGM.

Basri, Alwin: "Evaluasi Bauran Pemasaran Politik Pasangan Kepala Daerah dalam Pemilukada", Jurnal Interaksi, Vol. 2, n 1 (January 2013), pp. 30-39.

Casey, Kimberly L. (2008): Political Families in American Electoral Politics, St. Louis, University of Missouri.

Casey, Kimbely L. (2009): Family Matters: The Prevalence and Effects of Political Families in National Politics. Dissertation, University of Missouri.

Chang, Eric C. C.; Golden, Miriam A.: "Electoral Systems, District Magnitude, and Corruption”, British Journal of Political Science, Vol. 37, nº 1 (2007), pp. 115-137.

Dal Bó, Ernesto; Dal Bó, Pedro; Snyder, Jason: "Political Dynasties", Review of Economic Studies, Vol. 76, nº 1 (2009), pp. 115-142.

Denzin, Norman K.; Lincoln, Yvonna S. (2009): Handbook of Qualitative Research (Translation), Yogyakarta, Pustaka Pelajar.

Egner, Björn; Stoiber, Michael: “A Transferable Incumbency Effect at Local Level Elections: Why It Is Important for Parties to Hold the Mayor", ECPR Joint Session of Workshop, May 2007, Helsinki..

Fadli, Andi M. D.; Tobarasi, Indrawan; Rusba, Komeyni: "Kemenangan Petahan dalam Kontestasi Pilkada Serentak 2018: Ditinjau dari Perspektif Powercube”, Jurnal TAPIs, Vol. 14, no 2 (July-December 2018), pp. 116-139.

Jacobson, Gary C.; Kernell, Samuel. (1981): Strategy and Choice n Congressional Elections, New Haven, Yale University Press.

Kurtz II, Donn M.: "The Political Family: A Contemporary View", Sociological Perspectives, Vol. 32, no 3 (1989), pp. 331-352.

Lingkaran Survei Indonesia: "Incumbent dan Pilkada dalam Lingkaran Survei Indonesia”, Kajian Bulanan, 2 June 2007, at

http://lsinetwork.co.id/wpcontent/themes/kajian/bulanan/newsletter-edisi-nomor-2-juni2007.pdf.

Norris, Pippa. (1997): Passage to Power, Legislative Recruitment in Advanced Democracies, Massachusetts, Harvard University.

Paath, Carlos KY, “63,2\% Petahana Menangi Pilkada”, Beritasatu.com, 26 January 2016, at https://www.beritasatu.com/nasional/344756/632-petahana-menangi-pilkada.

Van Liefferinge, Hilde; Steyvers, Kristof: "Family Matters? Degrees of Family Politicization in Political Recruitment and Career Start of Mayors in Belgium", Acta Politica, Vol. 44, n 2 (2009), pp. 125-149.

Purwaningsih, Titin: "Politik Kekerabatan dan Kualitas Kandidat di Sulawesi Selatan". Jurnal Politik, Vol. 1, no 1 (August 2015), pp. 97-123.

Purwaningsih, Titin (2016): "Politik Dinasti dalam Pemilihan Kepala Daerah", Makassar, Universitas Hasanuddin.

Smith, Daniel M. (2012): Succeeding in Politics: Dynasties in Democracies, Dissertation, University of California. 
Trounstine, Jessica: "Evidence of a Local Incumbency Advantage", Legislative Studies Quarterly, Vol. XXXVI, nº 2 (May 2011), pp. 255-280

"Awasi! Ini 7 Celah Penyelewangan APBD oleh Petahana Jelang Pilkada", Batamnews.com, 11 September 2015, at https://www.batamnews.co.id/berita-6615-awasi-ini-7-celahpenyelewengan-apbd-oleh-petahana-jelang-pilkada.html.

"Faktor-Faktor Penyebab Kepala Daerah Korupsi", BPKP, 2016, at http://www.bpkp.go.id/puslitbangwas/konten/2674/16.050-Faktor-Faktor-Penyebab-KepalaDaerah-Korupsi 